\title{
Jadidism as an Educational System and a Political Movement in Turkestan (Central Asia)
}

\author{
Bazarbayev Kanat Kaldybekovich ${ }^{1}$, Tursun Hazret ${ }^{1} \&$ Sadykova Raikhan $^{2}$ \\ ${ }^{1}$ A. Yasawi International Kazakh-Turkish University, Turkestan, 161200, Kazakhstan \\ ${ }^{2}$ Al-Farabi Kazakh National University, Almaty, 050004, Kazakhstan \\ Correspondence: Bazarbayev Kanat Kaldybekovich, A. Yasawi International Kazakh-Turkish University, \\ Turkestan, 161200, Kazakhstan. Tel: 7-701-646-2295. E-mail: Kanat-08@mail.ru
}

Received: November 5, 2012 Accepted: November 20, 2012 Online Published: November 27, 2012 doi:10.5539/ies.v6n1p85 URL: http://dx.doi.org/10.5539/ies.v6n1p85

\begin{abstract}
This article throws light upon the history of the national-progressive movement of the late $19^{\text {th }}$ and early $20^{\text {th }}$ century, which is called Jadidism. The history of Jadidism and its evolution from enlightenment to a powerful political movement can be retraced in it. Jadidism became an alternative form of the intellectual renewal of Muslim society. The beginning of the movement was connected with the introduction of the phonetics, so called "usul-i jadid", method of teaching reading and writing instead of letter and syllabic one in maktabs and madrasas, that is a new method. The Jadids criticized religious fanaticism, required the substitution of obsolete religious schools for national secular ones, advocated the development of science and culture, supported the publishing of newspapers in the native language, the opening of cultural and educational establishments, which favoured the consolidation of the democratic forces of the society.

From the very beginning the Jadids were aimed to the reform of the traditional system of education of Muslim religious school, establishing new-method schools, publishing, theatre, social, and political and cultural institutions, which, under their influence, were turning into a powerful ideological weapon in the struggle against economical, moral, and political backwardness of the peoples of Turkestan more and more. They were eager to study the experience and progress of the other people of the world, especially the best practices of the Muslim reformers of the Crimea, the Volga Region, the Transcaucasia, Turkey, and Iran, who had already became aware of the progressive social and political, spiritual and cultural life of Europe.

The main merit of the Jadids of Turkestan consists in the fact that they were the first to ground political arguments of the national liberation movement against Russian colonialism. The national elite of Turkestan discredited the 'legitimacy' of the colonial form of government, and later it served as the basis of a powerful political movement.
\end{abstract}

Keywords: Central Asia, Jadidism, new-method schools, the national elite of Turkestan, modernization of the traditional society

\section{Introduction}

Jadidism, risen as an educational movement at the turn of the $19^{\text {th }}$ and $20^{\text {th }}$ century and declined under the attack of the Soviet power in the late 1920s of last century, still arouses interest not only in Central Asia, but also quite beyond its boundaries. This increasing interest is explained with the fact that the ideas proclaimed, but not implemented by the Jadids, have actual significance, which is not lost for this region.Initially, Jadidism arose as a narrow movement of cultural nature for the reform of the old system of Muslim education, for the necessity of European education for Muslims. In new-method schools children were taught with the use of a phonetic method, which was new for Muslims. The founder and an active proponent of Jadidism was Ismail Gasprinski, a Crimean tatar, murza and agrarian, publishing the newspaper "Tarjiman" ("Translator") in Bakhchisaray from 1883 to 1914. In the period of the revolution of 1905-1907 and during the subsequent years, Jadidism in Central Asia fell outside the initial limits of cultural nature and acquired a distinct coloration of the bourgeois-liberal political and ideological movement. The social base of Jadidism was mainly the bourgeois sections of the population of Central Asia and a part of national intellectuals. The Jadids followed Turkish enlighteners, and they were closely connected with Tatar and Azerbaijani progressive intellectuals. At the same time, they were trying to keep the 
masses of revolutionary actions. Before 1917, Central Asian Jadidism failed to acquire certain organizational forms. The Jadids were the name for those who spoke in favour of the need to eliminate some of the vestiges of feudalism, which restricted the rising bourgeoisie, in favour of the limited reform of Islam and religious schools, the adaptation of Islam to the bourgeois development of the borderlands of the Russian Empire and the needs of national bourgeoisie. But the Jadids had neither definite programme nor the leading center and statute. They were grouped around individual Jadid publishing houses, newspapers and magazines, which were legally published in Turkestan and Bukhara, around new-method schools, benevolent societies, etc. The leaders of Central Asian Jadidism were Mahmudkhoja Behbudiy, Munawwar-Qari Abdurashidov, Abdur-Rauf Fitrat, Ubeydulla Khodjaev (Turkestan), Faizullah Khodjaev (Bukhara), Palvan Niyaz Khodja-Yusupov (Khiva), etc. During the political events of 1917, the Jadid movement gained political overtones and became the official ideology of the political movement across the country. The representatives of the movement, leaders of such national political organizations as "Shuro Islamiya", "Shuro Ulema" were the ones who formed the essence of a national idea. The socio-political and social and cultural ideas, raised by them, were widely used among the local population as an alternative to the Soviet module for the modernization of social life. However, the Bolshevik power, backed by the army, did not give an opportunity to realize the Jadids' ideas, and the representatives of Jadidism were subjected to political repression and persecution.

\section{The Beginning of Jadidism in Turkestan}

The Arabic word 'jadid' (literally 'new') was initially used to call those who being under the influence of the didactic ideas of the prominent Crimean Tatar enlightener Ismail Gasprinski (1851-1914), opened new-method schools, where not only religious, but also secular sciences were taught (Gankevich, 2000).

The emergence of Jadidism associated precisely with these schools ("usul-i jadid"). During his study at the Sorbonne, the founder of new-method schools Ismail Gasprinski familiarized with the new analytical and phonetic method of teaching the alphabet and was eager to reform the obsolete system of Islamic education. On returning home in 1884, he opened a "usul-i jadid" school, where he taught 12 students to read and write for 40 days. Later he wrote: "The result exceeded all my expectations, and then this method was implemented in a few more schools. Visitors from the regions familiarized themselves with these schools and also accepted the new method in more than 200 schools".

I. Gasprinski advocated his ideas from the pages of the newspaper "Tarjimon" ('Translator'), published by him, which opened a new world for its readers, the world of advanced, forward-looking ideas. Among the first subscribers of the newspaper were those from Marghelan, Tashkent, Bukhara, Samarkand, Turkestan, and Akmechet cities. Even the Emir of Bukhara Said Abdullah Ahad Bahodir, who were travelling around the central cities of Russia between 1892 and 1893, made a special trip to Bakhchisaray and met with Gasprinski in February, 1893. The Emir generously rewarded the editor's family and his staff. He made Gasprinski a holder of the Golden Order of the Rising Stars of the third class.At the invitation of the Emir, Gasprinski visited Tashkent, Samarkand and Bukhara for the first time, and with the Emir's permission he opened the first in Turkestan new-method school in Bukhara in 1883. Those who shared his ideas in Samarkand welcomed him warmly in the ancient capital of Amir Temur (Tamerlane) and also opened a new-method school there. The school was opened without official permission of the colonial authorities and was soon closed by the order of the Head of the Educational Department of the territory. The school in Bukhara didn't exist for a long time either.Yet, Gasprinski's ideas penetrated in Turkestan together with a new-method school. From the pages of his newspaper, he appealed to the Muslim people of Russia, who had made a great contribution to the development of the world's civilization and were living in backwardness and ignorance, urging them to become educated and cultured people. Gasprinski acquired hundreds of supporters who promoted and disseminated the ideas of the great teacher. Thus, Gasprinski laid the foundation of the education reform of Turkic peoples. The leaders of the Jadid movement were Munawwar Qari Abdurashidkhanov, Abdullah Awlani, Ubaidullah Khodjaev in Tashkent, Mahmudkhoja Behbudi, Abdukadir Shakuri, Saidakhmad Siddiki-Ajzi in Samarkand, Fitrat, Faizulla Khojaev, Sadriddin Aini in Bukhara, Hamza, Ibrat, Chulpan in the Ferghana Valley, Palvanniyaz Khoji Yunusov and Baba Akhun Salimov in Khiva, and Konurkhoja Khodjikov in Turkestan city. They were the pioneers of Jadid beginnings. Not limiting themselves with the opening of new-method schools in Turkestan, they helped young people to be sent to prestigious educational institutions of Russia, Turkey, Egypt, and Western Europe for study. The Jadids targeted young people to receive education, master secular science, and faithfully serve the people and the motherland as doctors, engineers, lawyers, agronomists, religious leaders, and statesmen. Among the young people who were sent for study from Turkestan to Turkey was Fitrat, the future ideologist and prominent representative of Jadidism, received education in an old school and a madrasa. Once he proved himself as a talented and progressive-minded young man, the Jadids sent him to Turkey for study. Between 1908 and 1913, 
Fitrat witnessed the first steps of the Turkish Revolution and its victory over the feudal system. Impressed by what he saw and read, critically reflecting on the events, taking place in Bukhara, he was convinced that the main impediment to progress was the religious fanaticism of the masses. He came to the conclusion that in order to change and improve the lives of working people, in the first place, it was necessary to fight against the darkness of ignorance and its "leaders", to discredit them, to rent off their hypocritical masks. The books "Spor" ('Dispute') and "Indiyski puteshestvennik" ('Indian traveller'), written and published by him in Turkey, ruthlessly exposed the reactionary clergy and state foundations of the Emirate, and being secretly distributed in Bukhara, shook the young people.

The hero of his book says: "Here it is, the sacred Bukhara, educated 400,000 of learned men and sent them to all parts of the world. It used to be the mistress of the powerful scientific forces ... Now, alas! Unfortunately, I realize that this heaven of luminaries in science, this paradise of the world of humanity, this well-maintained home of the world's sciences ... in the presence of all the ways to progress, it became a country, surrounded by mountains of stupidity and put into chains of contempt! Our fathers clearly understood the meaning of the great saying: "Are knowledgeable men and ignorant ones equal to each other?" (Fitrat, 1990).

The message of Fitrat's book, like the goal and all the tasks of Jadidism, purposes to change radically and improve the lives of the miserable, uneducated, wild and poor people through education.

In this analysis, it is possible to reveal the presence of two main factors that influenced the formation of Jadidism in Turkestan. The first factor was generated by the inability of the mechanism of self-renewal of the country's traditional society in the conditions of the colonial power, and this resulted in falling the social development of the local people into stagnation. This situation complicated the process of the acceptance of the elements of civilization of the colonial oppression. The second factor was generated by the colonial superiority of tsarist Russia, setting the goal of Russification of the local population, trampling on their traditions and customs. This goal of modernization accelerated the assimilation of Turkic peoples. Under these circumstances, there arose Jadidism, the best movement that was able to lead society out of the impasse and bring it to the world's civilization, keeping all national traits.

\section{The Educational Activities of the Jadids}

An extensive system of traditional educational establishments and the Jadid schools, opened at the turn of the century, influenced the level of the education and awareness of the local population. For example, there were 5892 schools and 353 madrasas in the country in the early $20^{\text {th }}$ century. (TSGARUz. F.47, Opis' 1, delo 979, list-81(F.47, Inventory 1, file 979. Sheet-81)). Even the tsarist government recognized the fact that the local population had a high level of literacy. On March $14^{\text {th }}, 1909$ governor-general of Turkestan P.I Mischenko wrote to the Minister of Public Education of Russia: "The literacy of the natives of Turkestan, especially in its main regions such as Syrdarya, Ferghana and Samarkand, is at a very high level, which is much higher than that of European Russia. A well-developed system of primary schools (schools), secondary and higher education institutions (madrasas) tightly covered most of the territory".

This traditional educational system, possessing its ideological influence, from the very beginning was tightly controlled by the colonial administration. The decree of the Russian emperor, issued on May 17, 1875, was the ground for the foundation of Turkestan department of educational establishments, which was granted a power to exercise control over the activity of Russian educational establishments, as well as over the national ones. And on March 14 1894, governor-general Vrevsky approved the post of the third inspector of Turkestan public schools, who had the direct oversight of the traditional institutions of the settled and nomadic population. This inspector served as the governing body in madrasas and schools, so Muslim schools completely passed under the control of the department of public education.

Under those circumstances, the educational activities of the Jadids of Turkestan, becoming an alternative to the activity of the colonial administration in the renewal of education in the territory, acquired a reformative character and had a direct influence on the process of the education of the people. Instead of the traditional education, inseparable in its essence from the medieval scholasticism, they proponed a system of schools, where new methods were used in teaching ("Usul-i sovtiya"). Soon the schools became new-method ones ("Usul-i jadid maktablari”). Besides religion, they were teaching science, the Russian, Arabic and Persian languages, and the genesis of the future intelligentsia was formed. At first, the Jadid schools used textbooks written by Tatar and Azerbaijani enlighteners, but later Turkestan Jadids started to publish textbooks and tutorials themselves. In 1903 and 1904, the books "Kitabul-atfol" ("A book for children"), "Muhtasiri zhugrofiya Rusiya" ("Short geography of Russia") by Mahmudkhoja Behbudi, in the following years, the books "Muallem Awwal" ("First 
Teacher"), "Muallem soniy" ("Second teacher") and others were published, and in 1905, the number of the Jadid schools in the country reached 35 (Tabyshalieva, 1993).

The main advantage of the Jadid schools was that their students mastered literacy in a few months, besides that, the schools were equipped with modern facilities and teaching aids, namely maps, globes, abacus, blackboards, etc. In 1903 and 1904, Mahmudkhoja Behbudi visited St. Petersburg, Moscow, Kazan, Orenburg, and the Crimea, where he met Ismail Gasprinski who made some changes in his projects to reform the society through a humanitarian way and thoroughly fortified him on that way. Adhering to that path of enlightenment, in 1905 he organized a school with new methods of teaching in the village of Kaftarkhona of Samarkand region and began to teach more than forty students for free ["Samarkand". 1906. May 20].

The colonial authorities feared national schools, including the Jadid ones, believing that they and their activities reinforced the anti-colonial struggle. The measures, taken by the official authorities in relation to these concerns and the limitation of the activities of these schools caused discontent of the national elite. As a result, the imperial government was forced to change the policy of public education, undertaken in the territory. The tsarist government, examining the issue very carefully, created special commissions within the department of local educational establishments. The commissions were aimed to support tight control over national schools, and, basing on the information, provided by these commissions; it developed and adopted common rules for the management of new-method schools. On January 25, 1912 governor-general A.I. Semenov approved the rules, where the requirement was stated: "Secondary new-method schools are opened with the permission of the inspection of public schools. It should be offered to urban and rural communities, which are the founders of the schools, to adopt the nationwide Russian language for children's education”(TSGARUz. F. 47, Opis' 1, delo 149, list-10 (Inventory 1, File 149. Sheet-10).

Progressive youth, feeling the breath of a new historical time, took up the study of the Russian language. In her recollections, Kholida Ayni (Ayni, 1982), the daughter of the famous Jadid writer Sadriddin Ayni, gives a conspicuous fact about her father. In August 1915, the kushbegi summoned 50 Bukharan Jadids and made each of them write a note saying that they would not read the above-mentioned newspaper. These facts indicate that not only colonial authorities, but also the conservative forces of the country fought against the Jadids' ideas.

The Interior Ministry, which gave a special importance to the Jadid schools as a strategic object, on September 22, 1913 sent Turkestan governor-general a special letter that read: "New-method schools by teaching in one (the Turkic language) are campaigning for Muslims' rallying, and their school reformers have the purpose to harm the interests of the Russian statehood and, basing on the religious and national isolation, to unite all Muslims". These two documents became the base for the local colonial power to create obstacles to the movement, supported the interests of the local people in the field of public education.

Publishing activities were widespread along with the educational activities of the Jadids. Many books and periodicals were published in Turkestan. At the beginning of the century, the number of newspapers and magazines was 15. Over the years, Abdollah Avloniy was the editor of the periodicals such as "Khurshid", "Turon", Mahmudkhoja Behbudy edited "Samarkand", "Oyna" ("Mirror"), Munawar Qari Abdurashidkhanov and Mustafa Shokai edited the newspapers "Kengash" and "Birlik tuy", respectively. The latter was published in the indigenous language. Soviet historians one-sidedly characterized these periodicals as reactionary, pan-Islamic, pan-Turkic ones, but the periodicals played a cultural, educational and politically organizational role in the political and moral life of the people.

In their political positions, the Jadids did not expect Russia to be divided; the matter was the co-operation of Muslims, aimed at the destruction of the colonial chains. The Islamic factor became an indicator of the political self-consciousness for the Muslims of Central Asia in their sense of spiritual and cultural solidarity with the Muslims of the other regions of Russia and all the world (Azamkhujaev, 2000).

Gasprinsky's idea of "unity in language, thoughts and work" continued its life among the representatives of Turkestan society as the idea of national renewal, designed to conform the peoples of Central Asia to the world civilization. The system of their beliefs focused on the global human values and was closely linked to the national interests. We see that this movement was not only of local significance, it became a phenomenon, that obtained an extension of human civilization, and enlightenment, the main idea of their programme developed into the idea of political independence of the nation. The main characteristic of the Jadid movement was its Eurasian character, where the struggle for a democratic society, against the colonial government merged with the struggle against the feudal despotism and religious fanaticism. In their program, they considered the escape from colonialism alongside with the elimination of the feudal order. 
Thus, the programme of the Jadids, the main bearers of the ideas of enlightenment in Turkestan in the late $19^{\text {th }}$ and the early $20^{\text {th }}$ century, was as follows: first, to reform Muslim public education and prepare highly qualified specialists in the essential sectors of culture, science and technology; secondly, with the help of trained professionals to develop the economy, industry and agriculture of Turkestan, making it one of the highly developed cultural, scientific and technical territories of Russia; thirdly, to raise the living standards of the people, to improve their well-being; fourthly, to form the national capital, to promote the increase of the number of rich and wealthy people, and, fifthly, with the help of qualified local professionals to change the infrastructure of the society, that is, to conduct the indigenization of the state apparatus, which was a necessary step in the formation of independent states in Turkestan.

The Jadids' programme of this type could satisfy neither tsarist regime nor Soviet power. They both did everything to prevent and prohibit the activities of the Jadids' and destroy them physically. Soviet authorities, with the help of the writers and journalists who were loyal to them declared the Jadids to be nationalists, ideologues of bourgeoisie and "expose" their actions in the press. The terms "pan-Turkist" and "pan-Islamist" were invented to label them.

Despite such aggressive attacks of the totalitarian regime, the Jadids did not only express the interests "of the local bourgeoisie", but demanded from it, primarily, to care about the quality of their goods, their competitiveness, they advocated the need for purchase of modern equipment and technology from the developed European countries. Consequently, the educational activities of the Jadids may be said to cover not only the sphere of education and culture, but also the economic modernization of the country.

\section{The Jadids' Concept of the Social and Cultural Modernization of the Society}

The idea of the social and cultural modernization of the society was able to form in the concept of the representatives of the national elite of Turkestan. One of the public figures, who were able to bring this concept to the level of the national idea, was Mahmudkhoja Behbudi, the leader of the Jadids. He came from a religious family, received an excellent religious education, and in 1899, at the age of 25, visited some cities of Russia, the Crimea, Iran, Turkey, and Egypt. During the trip, he was given an opportunity to compare the achievements and shortcomings of the social and political life of the local people with the real situation in Turkestan. As the publisher of the magazine "Oyna" ("Mirror"), he presented his social and political views in "Memoirs of travel". However, as a result of the trip, he realized that many things needed to be changed and improved for progress in Turkestan in tune with the civilizations of those Muslim countries that he visited.

In his articles, Behbudi not only advocated the project of a school reform, but also expressed hope for the further development of the education system on the whole. With these ideas, in 1914 he had a second visit to Turkey, Egypt and other countries, where he remained for eight months. The trip was so successful that after it he became engaged in political activities more actively.

The significance of the Jadid movement is determined not only by the fact that they reformed the Muslim obsolete system of public education, but also their being the founders of the national press, literature and theater. They were truly pioneers, born before their time. As is generally known, the roots of Turkestan literature throw back. However, the coming of the twentieth century demanded of the Jadids the literature that would truly reflect the real life of the people, their worries, anxieties and aspirations that could awaken the people. The Jadids created such literature, which was dear to the people, both in language and in content.

The founders of the new literature were Fitrat and Chulpan. Their poetry, glorifying the ideas of patriotism and love of freedom, had a great influence on the consciousness of the masses. The educational, anti-colonial and freedom-loving ideas of Jadidism found their vivid expression not only in poetry, but also in prose. It is significant that M. Behbudi, before he showed himself as a writer and a publisher, wrote the first Uzbek play "The Patricide" (1911), and the production of it in 1913 is considered to be the birthday of Uzbek theater. Being keenly aware of the value of theater, its effect on the viewer, in the 1910s, he and his followers wrote more than a dozen plays on the burning issues of the day. In the plays, they showed the tragic consequences of the lack of education, drug addiction, weddings that are ruinous for the people, bey-feudal treatment of women, etc. The performances, based on these plays, found a great response among the audience. The first Jadid theater troupes toured with the productions almost all Turkestan and showed that the theater was literature, intended for the general public, and the performance was a novel, the events of which occurred on the stage (Sharipov, 2002).

It should be said that before 1917 the Jadid movement had no its programme. Up until 1917 Fitrat's works "The Dispute" and "An Indian traveler" served as the unofficial programme of the Jadids. "The Project of the Committee of the Young Bukharans in Bukhara", written in 1917 with the participation of Fitrat, is one of the few legal documents, which came to us. Consisting of 13 chapters, such as "Land and water matter", "Waqf 
lands", "Military science", "Finance", "Internal affairs" and others, the project is more like the political program of the Young Bukharan Party, aimed at gaining power and control of the territory in the future.

Besides that, the project focuses on enlightenment, the main activity of the Jadids. The authors of "The Project" wrote: "The minister of education should be appointed for the leadership of all the schools in the country, opened on public funds, for such actions as the appointment of teachers, opening higher educational establishments, working out curriculum, and so on.

In addition to state and waqf ones, schools can be opened by anyone. No one has the right to interfere with that. Those who graduated from the educational establishment are awarded with diplomas of due form by the Minister of Education with the assistance of the Higher Pedagogical Council. For example, the diploma for the title of a mullah, a teacher, a mufti, a qadi (judge), etc.“ (Khodjaev, 1970).

In order to explain the situation arisen in the ranks of the Jadids of Bukhara, switched from didactic tasks over to the problems of policy, we think to be necessary to turn to the book "On the history of the revolution in Bukhara" by Faizulla Khodjaev, who led the Young Bukharan Party along with Fitrat.

Referring to the Jadid movement in Bukhara, Fayzulla Khodjaev wrote: "Jadidism experienced a kind of crisis in 1914 and 1915, when under the pressure from a double censorship, the existing newspapers were closed, and the cavils of the emir administration to legal societies were intensified.

Another point contributed to the crisis. On returning home many students having been educated in Constantinople and Orenburg did not agree with their former teachers, the old Jadids. They demanded the advancement of the political moment, a precise formulation of political objectives.

These new requirements caused... the first differentiation of Jadidism, the first division of its ranks into the Jadids of old wing and the left one, consisting mostly of young people.

The former Jadids Fayzulla Khodjaev, Fitrat, Munawwar Qari Abdurashidkhanov and others paid special attention to the training of highly qualified national personnel in the fields of education, science, culture, agriculture, etc. Towards this end, in the early 20s, they sent more than 60 talented Uzbek, Kazakh, Kyrgyz, Tatar, Tajik boys and girls to Germany for study. Galimjan Idrisi, a Tartar, was assigned the leader of the group. The leaders of Bukhara and Turkestan Republics Fayzulla Khodjaev, Turar Ryskulov and others, visiting Germany in 1922 and 1923, always cared about living and studying the youth of Turkestan and restrained the forces, hindering their successful study. An example is their resistance to the slanderous accusations, placed on the pages of the newspaper "Fergana" on June 5, 1923, in the article "Do not want to send students abroad".

In the early 20s, they organized the company "Nashri Maorif" ("Educational Edition"), tried to prevent the destruction of the cultural heritage, i.e. books, monuments, works of applied art, etc. As a result of the expeditions organized by them, "Kutadgu bilig" ("Science to be happy") by Yusuf Balasagun, a masterpiece of medieval Turkish classical literature was found, and subsequently studied and published.

The primary importance of the social and cultural modernization of Turkestan society, conducted by the Jadids, lay in offering national values as an alternative to the class values of the Bolsheviks. The basis for this conclusion was the results of the scientific analysis of the existing facts and information. The formation of the social and cultural development of the newly independent republics of Central Asia in this direction confirms the viability of the ideas, raised by the Jadids in the early twentieth century.

\section{The Jadids in the Political Life of Turkestan}

Founded after the February Revolution of 1917, the regional representative body "Shuroi Islamia", the Organization of the Muslim Council was created under the influence of All-Russian Muslim movement at the suggestion of the Jadids of Turkestan. This name was chosen to highlight this political organization among the other organizations, established on the European model. The political activities of the Muslim Council in Turkestan were so intensive and influential, that the Bolsheviks, who came to power, had to abide by it.

Therefore, Soviet historians accused the Jadids of being nationalists, of fostering feelings of hostility towards the Russian people, of being isolated from the people, of the striving to please the national bourgeoisie. If it were true, there would have been neither a Russian nor a Jewish, nor a Polish, nor a Kazakh in the Turkestan Autonomous Government and Munawwar Qari Abdurashidkhanov, Salimkhan Tillyakhanov, Fitrat, Chulpan, Batu and others would not have married Russian women, M.Behbudi would not have advanced the slogan "Speak not only two, but four languages!", meaning the Russian and one of the European languages besides the Uzbek and Persian ones. 
M.Behbudi, who traveled a lot about the countries of the world, studied the structure of the state not only in eastern countries, but also in European ones, gave brief information about them in his textbooks and, based on their political system, specified three groups: 1) monarchical, 2) constitutional and parliamentary, and 3) republican. He being a citizen of the Emirate of Bukhara, knew perfectly that a monarchical state cannot give people happiness and freedom, therefore he wholeheartedly supported his colleagues in their aspiration to see Turkestan as a constitutional and parliamentary state (Behbudy, 1999).

A policy of violence, pursued by the colonial administration in the territory, faced to the strong pioneering movement of the Jadids of Turkestan that had intellectual, cultural and humane nature. A new, educated generation of Turkestan merchants, intellectuals and religious figures looked at the colonial power with doubt of its "legitimacy" for the first time. Mahmudkhoja Behbudi volunteered to arouse the hidden forces of the people in order to restore the national statehood and achieve freedom, and his multilateral social and political activities resulted in his becoming a real "father" of the Jadids of Turkestan.

The question: "What was Behbudi's view of the political situation in Turkestan?" can be answered the following words. He linked the progress of the people with enlightenment, with a radical change in its political status and gaining independence. In his numerous articles, he denounced the colonial policy of the tsarist government and mercilessly criticized the Russian Provisional Government and its laws. He knew that the people would not be able to achieve independence without fight. In the article "The presentation of the truth", he said that in history there were many examples of winning of own rights, that is to say: "The rights have to be won, no one will give them to anyone, peoples and nations can achieve their rights only united around a political movement ... We, Muslims, especially Turkestan Muslims do not want anyone or anything to restrict or put pressure on our religion and nation, we have neither a desire nor an aspiration to threaten someone's independence,". In this regard, he supports Munawwar Qari's idea: "Freedom is not given, it has to be taken" (Munawwar, 1917). However, he does not support Munawwar Qari's thought that freedom can be won with blood and sacrifice. Behbudi, like most of the Jadids, was on the side of bloodless fight against colonialism, so he was against the revolution. He thought that it was possible to achieve much, carefully following the activities of the State Duma and carrying on parliamentary struggle. Despite the fact that he was a supporter of the movement for autonomy, he thought the way of evolution to be the best in order to make progress. He believed that if Turkestan was a part of Russia, it would achieve independence.

On the debate over the state system at the congress, held in Turkestan after the February Revolution, Behbudi proposed that Turkestan take a special place in the structure of federal Russia: "In Tashkent there will be Centres and Medjlises consisting of a few people from each city and county of five provinces of Turkestan. They will engage in the legislative and executive activities, and tax collection. The Medjlis will mediate between Russian government and Muslims ... Naturally, it is necessary that the most of the representatives were Muslims, and least of them were Russians, the work should be carried out not by fiat or by force, but on the basis of compromise" (Behbudy, 1917). These ideas were reinforced by a policy document "The Project of Autonomy" adopted by the party of "Turk Adami markaziyati" (Turkic Federalists), founded in Skobelev city on July 12-14, 1917. M.Shokay writes about the preparation of this document: "National Center" prepared and entrusted to Shaislam Shaahmetbek to provide the documents necessary for the autonomy of Turkestan. He received all possible assistance in it from Mahmudkozha Behbudi, Ubaidullah Koja and me” (Shokai, 1999).

The Jadids, who wholeheartedly supported the ideas of the All-Russian Muslim movement, emphasized the autonomous self-dependency in the federal state structure of Russia, stated in this document. Behbudi advocates unity in the struggle for national liberation with his words: "We must make possible the creation of Russian Muslim federation without breaking ties with Russia, moreover, we, Turkestan Muslims must reject the positions of "old method adherents" and "the Jadids" and create a united alliance". Of course, Behbudi understood that the division of the national liberation movement into the groups, based on religion or ethnicity, weakens the struggle against the colonial system, and he believed that it was necessary to prevent bloodshed, the division of land and wealth on the way of the consolidation of Turkestan, because only a peaceful, bloodless way could bring to social and economic progress.Behbudi participated actively in the establishment of Turkestan mukhtariat, was the ideological inspirer of this process, and was elected a member of the Provisional Government of Turkestan muhtariat. In the early years, speaking about autonomy in his speeches and articles he meant a federation. Later, the concept of "mukhtariat" was processed politically, and in accordance with the Congress's decision got a new concept, "autonomy".

The declaration of the autonomy of Turkestan, which became the first victory of the national-democratic forces in the region, was not supported by "Shuroi Ulema". This movement united by the struggle against the colonial government, divided into groups, as the "father" of the Jadids, Behbudi said with regret: "Our differences in 
beliefs have destroyed the unity, these troubles are our misfortune. If Turkestan joined, it would be the owner of the power of 15 million people that would be capable of shaking the earth" (Behbudy, 1917).

The hostility within the national liberation movement of Turkestan, due to differences in religious beliefs, was particularly noticeable in the solution of many matters arisen. For example, although the equality of women found support among "Shuroi Islamia", Muslim ulema held the opposite view in this matter. According to Behbudi, despite the fact that the ulema of Tashkent were asked to settle the matter of participation "of women in elections to the women's commission in yashmak, without men" many times, all these requests were not honored. National interests occupied a priority position in Behbudi's activity, that is, he supported the unification of all political forces, which were the supporters of the ideas of the national movement. According to Zaki Ahmed Wali, he did not like the Bolsheviks. Munawwar Qari, Behbudi and the rest of the Jadids spoke out against the Cadets and the socialists. The article "The best in any business is the golden mean" written by Behbudi in 1906, provided an appraisal of the four parties that had a wide spread occurrence in the metropolis. He called the first party a bureaucratic-despotic one, and the order, which it established, totally unfit for the free development of Turkestan. In his opinion, the program of the Social-Democratic Party would be harmful to the Muslims, the financial paragraphs of the programme were invariable, and the human's views on the family were not harmonious and "absolutely unsuited" for the rules of sharia. He did not find warm words about the Cadet party either, and in 1917 at the April congress, being disillusioned with the party because of its great-power ideas, subjected its positions to harsh criticism. The programme of the "Union of Russian Muslims" was similar to the one of the Cadets', but the party united Muslims with the religious, economic, and ideological points of view, so it was considered to be the most acceptable for the conditions of Turkestan (Behbudy, 1906). The elite, supported the Jadids' views, took these ideas of Behbudi as policy tasks for the political unification and created the ideological foundation for the establishment of the "Shuroi Islamia" party in the territory after the February Revolution.

Beginning with 1918-1919, the Bolshevik cadres were constantly sent to Turkestan from central Russia, in the mid 20s they flooded all the governmental agencies. Turkestan, in the full sense of the word, became a colony of the Soviet empire. The Jadids didn't want to put up with this situation. It was the time when a few of the former Jadids, who held high positions at top echelons of Soviet power, raised the issue of indigenization of the state apparatus. The Bolsheviks, stroke a blow on this few of the ex-Jadids, declared them nationalists and isolated from the society.

The Bolshevik leaders tightened the supervision of the activities of the ex-Jadids. For example, in 1919 Mahmudkhodja Behbudi with his friend Mardonkuli went abroad to participate in the peace conference in Paris. However, in the territory of the Emirate of Bukhara they were captured and brutally killed by the emir's executioners, and according to contemporaries, it was done with the help of the Bolshevik agents. The other members of the autonomy Ubaidullah Khodjaev, Saidnasyr Mirdjalilov and the leader of the underground organization "Milly ittihod" Munavvar Qari Abdurashidkhanov, and the others were subjected to repression since 1923. Ubaidullah Khodjaev languished in a cell of Butyrskaya prison with a Tatar politician Ilias Alkyn more than a year. At the end of 1929, Munavvar Qari Abdurashidkhanov was charged as one of the leaders of the counterrevolutionary organization "Milly ittihod", in 1930 he was shot and secretly buried in Vagankovskoye Cemetery with his comrades-in-arms Salimkhan Tillyakhanov, Said Ahrori from Uzbekistan, as well as the fighters for independence Zhusubek Aymautov, Abdurahman Baydildin from Kazakhstan and others. At the end of 1937, all the former prominent Uzbek, Kazakh, Tatar scientists and writers such as Abdurauf Fitrat, Gazi Alim Yunusov, Abdullah Qadiri, Chulpan, Bulat Saliev, as well as the state leaders of Uzbekistan and Kazakhstan Faizullo Khodjaev, Turar Ryskulov, Alikhon Buklikhanov and others were shot as the agents of foreign intelligence services, ardent nationalists, Pan-Turkists, fighting against the policy of the Soviet power. Thus, by the end of the thirties no figure of Turkestan Jadid movement escaped his life of execution by a firing squad. In 1937, all the former Jadids were destroyed. And even after their killing, until the mid-80s Jadidism was a taboo subject, and the names of the great representatives of this movement, such as Behbudi, Chulpan, Fitrat and others were impossible to mention without the label of "the enemy of the people" or "a nationalist".

The political and ethnic processes, occurred in the first quarter of the twentieth century in Turkestan, determined the areas of socio-political development. If the Jadids had not had the ideas to substantiate the nature and content of this development, as well as the political movement of the masses that had realized these ideas, the totalitarian power would not have met with strong resistance and it would not have reckoned with the national interests of the local people, and as a result, today's independent Central Asian states would get a completely different look. 


\section{Method}

In the theoretical and methodological basis of the research issue, the authors relied on the latest achievements of historians. During the study, a comparative historical source study analysis was conducted in order to classify the nature and content of the Jadid movement as a historical phenomenon. In the same way, the scientific work and socio-political activities of the brightest representatives of Jadidism were summed up by analyzing their literary works and social and political essays, and their political views were studied by the generally accepted scientific methods, such as the system-structural and theoretical cognition. In the appraisal of the socio-political history of Jadidism the authors were guided by objectivity principle. Due to the fact that the political, ideological, social and cultural phenomena of the movement were multilateral and contradictory, Soviet historiography, which described the phenomenon, was critically evaluated. Since the object of the research is many-sided, and the subject is complex, the studies took into account the requirements for the definition of their relationships and inner independence. The study used the methods that allowed the authors to complement the traditional historical consciousness, to restore historical truth through historiographical analysis to confirm or disprove some conclusions.

The conclusions and generalizations, made in the article regarding Jadidism and socio-political, cultural and educational ideas of the Jadids, can be used to update the curriculum of bachelors and undergraduates in specialty "history", as well as for forming of educational complexes in this area.

\section{Conclusion}

The origination and formation of Jadidism in Turkestan had deep historical background. As the research conducted in Turkestan Territory showed, there were two main factors that influenced the formation of Jadidism in Turkestan. The first factor was generated by the inability of the mechanism of the self-renewal of the country's traditional society under colonial power conditions, resulting in the stagnation of the social development which the local people fell into. The influence of Russian civilization, with which the economic relations were relatively more developed, and which came face to face with the medieval conservatism in Central Asia. It made difficulties for the advancement of the civilization of the colonial power. The second factor was generated by the colonial superiority of tsarist Russia, which set the goal of Russification of the local population and trampled their traditions and customs. This goal of modernization could have accelerated the process of assimilation of Turkic peoples. In these circumstances, there arose Jadidism, the best movement that could lead the society out of the impasse and bring it to the world's civilization, keeping all national traits.

Despite the fact that the Jadids and colonial authorities had the similar goals of education, from an ideological point of view they were antithetical, so the Jadid educational system was not supported by the colonial power. Yet, with the support of masses the new-method schools were widespread in the territory and made certain progress in the improvement of literacy. Along with this, the educational activities of the Jadids also covered the economic modernization of the territory.

The Jadids' ideas about the social and cultural modernization of the society were not accepted by the Soviet government, but it had to give class nature to some provisions and use them in the program of reforms. It was related to the granting of autonomy to the local population and the renewal of the education and culture. The social and cultural development of the newly independent Central Asian republics have formed in the same direction, which demonstrates the vitality of the Jadids' ideas, risen in the early twentieth century.The political colour of the Jadid movement strengthened the ideology of the national liberation movement in the territory. Their evidence negated the "legitimacy" of the colonial power and the increased the opposition to colonial oppression of Russia. In addition, in its initial stage, the Soviet government was forced to reckon with the ideas of Jadidism. Thus, the political and ethnic processes in the first quarter of the twentieth century in Turkistan determined the directions of the socio-political development of the region. If the Jadids had not had the ideas to substantiate the nature and content of this development and the political movement of the masses to bring the ideas to fruition, the totalitarian power would not have met with strong resistance and it would not have reckoned with the national interests of the local people, and as a result, today's independent Central Asian states would get a completely different look.

The Jadids' ideas gained new meaning and direction in the public policy of the independent Central Asian republics, which came to existence after the collapse of the Soviet Union. One example of such cooperation is sending hundreds of young people to various developed countries, including Canada via "Bolashak", a government-sponsored program of the Republic of Kazakhstan. 


\section{References}

Ayni, K. (1982). Zhin' Sadriddina Ayni. Kratkiy biograficheskiy ocherk (Sadriddin Aini's lify. Brief chronological sketch). pp. 110-119. Dushanbe: Irfon.

Azamkhujaev, S. S. (2000). Turkistan Muhtoriyati: Milliy-demokratik davlatchilik qurilish tajribasi. p.168. Tashkent: Manaviat.

Behbudy, M. (1906, October 11). Hayrul Umur avsatuho. Gazette, Xurshid.

Behbudy, M. (1917, December 22). Muhtoriyati Turkistan. Gazette, Hurriyat.

Behbudy, M. (1917, June 12). Bayoni haqiqat. Gazette, Ulug Turkiston.

Behbudy, M. (1999). Tanlangan asarlar (Selected Works). pp. 18-19,146-150. Tashkent: Manaviyat.

Fitrat, A. (1990). Istorii indiyskogo puteshestvennika. (The stories of an Indian traveler), 7, 134. Tashkent: Zvezda Vostoka.

Gankevich, V. (2000). Na sluzhbe pravde i prosvescheniyu (Serving truth and enlightenment). Kratkiy biograficheskiy ocherk Ismaila Gasprinskogo (A profile of Ismail Gasprinski). pp. 238-260.Simferopol: Dolia.

Ismail Gasprinsky i Turkestan. (2005). (Ismail Gasprinski and Turkestan. Collection of article). p. 230. Tashkent, Shark.

Khodjaev, F. (1970). Izbranniye trudiv 3-h tomakh (Selected works in three volumes), 1, 128. Tashkent: Fan.

Munawwar, Q. (1917, 26 March). Hurriyat berilmas, olinur. Gazette, Nadzhod.

Sharipov, R. A. (2002). Turkistonda jadidchilik harakati tarikhidan (History of the Jadid movement).Tashkent: Oqituvchi.

Shokai, M. (1999). Isbrannoye. V 2-kh tomakh. (Selected works. In two volumes). T. 2. p. 289. p. 520. Almaty: Kaynar.

Tabyshalieva, N. (1993). Vera v Turkestane. Osherk istorii religii v Sredney Azii i Kazakhstane (Faith in Turkestan. Sketch of the history of religions in Central Asia and Kazakhstan). p. 97. Bishkek: Commercial and publishing firm. AZ-MAK.

TSGARUz. (Central State Archive of the Republic of Uzbekistan). F. 47, Opis 1, delo 979, List 81. (F. 47, Inventory 1, File 979, Sheet-81).

TSGARUz. F. 47, Opis 1, delo 149, List 10. (F. 47, Inventory 1, File 149, Sheet 10).

\section{Authors}

Correspondence: Bazarbayev Kanat Kaldybekovich. A. Yassawi Kazakh-Turkish International University $(\mathrm{PhD})$-program student. He is the author of 38 scientific articles. Scientific journals of Kazakhstan, Kyrgyzstan, Russia, Poland, Turkey and Hong Kong.

Contact data: 161200, Turkestan, South Kazakhstan Region, the Republic of Kazakhstan. Tel: 8701-646-22-95. (72533) 4-09-51. E-mail: Kanat-08@mail.ru

Tursun Hazret. Doctor of historical sciences. He works at A. Yassawi Kazakh-Turkish International University. $\mathrm{He}$ is the author of 47 scientific articles.

Contact data: 161200, Turkestan, South Kazakhstan Region, the Republic of Kazakhstan. Tel: 8701-728-72-76. (72533) 7-37-74. E-mail: Tursunhazret@mail.ru

Sadykova Raikhan. candidate of historical sciences Al-Farabi Kazakh National University.

Contact data: 050004, Almaty, the Republic of Kazakhstan. Tel: 8701-472-02-09. E-mail: sraya84@mail.ru 